Горан М. РАДОЮИЋ ${ }^{*}$ Универзитет Црне Горе Филолошки факултет
Оригинални научни рад

Примљен: 11. 03. 2020.

Прихваћен: 15. 07. 2020.

\title{
ДАНИЛО КИШ И ИДЕАЛ ЕНЦИКЛОПЕДИЈЕ
}

\begin{abstract}
У раду се разматра појам енциклопедијског наратива као начина да се опишу неки књижевни текстови. Као кључни издвајају се два елемента, знање, на једној страни, и жанровска и стилска разноврсност, на другој. Енциклопедија је један од кључних мотива у поетици Данила Киша, експлицитној и имплицитној, и његови текстови могу се читати и као енциклопедијски наративи. Енциклопедија се код Киша јавља у различитим видовима, од лектире, извора за приповиједање, до идеала коме се писањем тежи. Сан јунакиње у приповијеци „Енциклопедија мртвих” вишезначан је. Он је реализација жеље, тежње да на губитак оца одговори чувањем сјећања на њега. Она открива „Енциклопедију мртвих” као остварење идеала о свеобухватном знању и о савршеном писању. Тај се идеал, међутим, вишеструко подрива, и у самој приповијеци, а и читавом књигом која и сама функционише као синегдоха енциклопедије. Показује се и да, осим као знање и утјеха, тај текст може да се разумије и као облик моћи, начин да се овладава мишљењем. Тензија између тежње човјека да тотализује и контролише и свијести да је стварност постала сувише замршена да би се обухватила важна је карактеристика Кишове књижевности. Киш показује да књиге могу дјеловати на различите начине, а важну улогу ту има интерпретација.
\end{abstract}

Кључне ријечи: енциклопедија, енциклопедијски наратив, знање, идеални текст.

Термин енциклопедија је релативно стари термин, начин да се опишу, и вреднују књижевни текстови. Чини се, није било толико проблематично као данас када су критичари називали, по правилу велика, дјела своје културе енциклопедијама, нпр. Бјелински у XIX вијеку Евгенија Оюегина, или, вијек касније, кад Деретић каже како је Горски вијенаи енциклопедија живота и историје (Деретић 1996: 233). Бјелински, тако, истиче: „Оюегин се може назвати енциклопедијом рускога живота, и у највећој мери народном творевином”, додајући: „Он је за руско друштво био акт сазнања” (Бјелински 1948: 156). Бјелински ту очигледно мисли прије свега на тематику, као и на сазнајну функцију књиге - Пушкинов текст, а и неки други, разумије се као енциклопедија ако тематизује важне елементе друштва, и то чини на такав начин да друштво о себи сазнаје нешто суштинско. Слично је значење и код Дере-

\footnotetext{
*gmradonjic@yahoo.com
} 
тића. То важи у многим периодима: Хомер, Библија, Махабхарата, Чуанг Це, Данте, Рабле, Сервантес, Гете, Мелвил, Балзак неки су од примјера који се истичу у том контексту. Можда је посебна рецепција, истицање енциклопедичности и знак да је нека књига кључна за неку културу.

Рекло би се да је дошло до реактуелизације таквог приступа посљедњих деценија, а он је у вези са општим карактеристикама нашег времена, питањем интерпретације, статуса књижевности, знања, моћи итд. Тиме су се отвориле различите могућности.

Није лако разлучити о чему се заправо говори кад поводом књижевности говоримо о енциклопедији и је ли у питању неко одређено својство текста, или више својстава, је ли у питању жанр, или нешто друго. Када тај и сличне појмове примјењујемо на књижевни текст, енциклопедија се углавном јавља као метафора, и можда је управо у тој метафоричности дио проблема.

Едвард Менделсон, који је, изгледа, седамдесетих година прошлог вијека наново поставио проблем, на основу седам ремек-дјела из различитих књижевности Запада, ${ }^{1}$ долази до идеје о посебном жанру који је назвао енциклопедијским наративом и за који каже да је од средишњег значаја у западној књижевности (Менделсон 1976: 1267). Он сматра да енциклопедијски наративи „сви покушавају да дају пун опсег знања и вјеровања једне националне културе, идентификујући идеолошке перспективе из којих та култура обликује и интерпретира значење" (1269). Менделсон наводи да свака велика национална култура на Западу прозводи енциклопедијског аутора, који заузима мјесто националног класика (1268). Важна је фигура синегдохе. „Зато што су производ ере у којој је знање свијета много веће него што било која једна особа може да обухвати, они обавезно обилно користе синегдоху. Ниједан енциклопедијски наратив не може описати читав опсег стварне науке, примјери једне или двије науке служе да представе читав научни сектор људског знања" (1269). Менделсон примјећује још једну важну особину енциклопедијских наратива, а то је да су они, између осталог, еничиклопедије наратива, које „укључују, али и не ограничавају само на њих, конвенције јуначног епа, романсе потраге, симболистичке пјесме, билдунгсромана, психомахије, грађанског романа, лирског интерлудија, драме, еклоге и каталога" (1270). Другим ријечима, у таквом наративу налазимо различите жанрове, који се могу мијешати и комбиновати. Исто важи и за стилове: „сваки енциклопедијски наратив јесте енциклопедија књижевних стилова, у распону од најпримитивнијих и анонимних нивоа пословичког знања до најезотеричнијих узвишења високопарног стила" (1271). Додајмо, да су они, у складу са Бахтиновим учењем о роману уопште, ${ }^{2}$ енциклопедије свих могућих стилова, не само књижевних.

\footnotetext{
${ }^{1}$ Дантеова Божанствена комедија, Раблеов Гаргантиа и Пантагруел, Сервантесов Дон Кихот, Гетеов Фауст, Мелвилов Моби Дик, Џојсов Уликс, Пинчонова Дуга гравитације. Из неког разлога Менделсон се ограничио на западне писце.

${ }^{2}$ Бахтин, познато је, одређује роман као ,уметнички организовану друштвену говорну разноликост” (Бахтин 1989: 16), и наглашава дијалогичност као још једну важну особину романа. А о Оюегину Бахтин ће рећи да је то „енциклопедија стилова и језика епохе” (90).
} 
Насупрот томе, Стефано Ерколино тврди: „немогуће је априори установити низ својстава по којима би се, мање или више легитимно, неки роман могао одредити као енциклопедијски, пошто се енциклопедизам не може поистоветити са неким књижевним жанром, нити се некоме може приписати” (Ерколино 2014: 135, истакао аутор). Према Ерколину, „имамо посла са енцииклопедијским модусом, који можемо одредити као одређени естетски и когнитивни став који се састоји из мање или више узвишене и тотализиpajyћe наративне тензије у смеру синтетичке репрезентације стварности и хетерогених домена знања" (135, истакао аутор). Кад је у питању знање, Стефано Ерколино наводи да свака енциклопедијска нарација има два фундаментална елемента: синтезу и хетерогеност: „Енциклопедијско знање је, по дефиницији, хетерогено знање. Одредницаิ које сачињавају енциклопедију има много, баш као и обухваћених поља знања, што подразумева и извесну концизност у енциклопедијском излагању" (134). Ту, наравно, не смијемо изгубити из вида смијех и пародију.

Можда би се енциклопедијски наратив могао посматрати као модел писања, који може имати различите реализације у различитим контекстима. Па и на плану вриједности које представља, афирмише или критикује.

Ваља имати на уму и то да, било да је разумијемо као жанр, или као

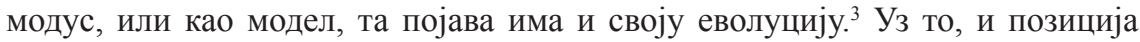
из које читамо неки текст није занемарљива, јер, у зависности од различитих структура, склони смо да у текстовима тражимо, и проналазимо или конструишемо, различите елементе, и да им приписујемо већи или мањи значај.

У енциклопедијском наративу као моделу издвајају се два елемента: на једној страни знање, и, на другој страни, жанровска и стилска разноврсност. Ти општи елементи отварају могућности за различите варијације. На другом мјесту (Радоњић 2016: 263-266) покушао сам да направим разлику између два вида енциклопедијске прозе, оба метафикцијска, у којима долази до проширивања: у једном виду, карактеристичном за романе као што су Хазарски речник Милорада Павића или Школице Хулија Кортасара, као и у жанру вијенца приповједака, долази до експанзије текстова о истом свијету; у другом виду, карактеристичном за Борхесове приповијетке или за Кишову приповијетку „Енциклопедија мртвих”, уводе се нови наративни нивои, што доводи до експанзије свјетова. Притом, та два модела могу се комбиновати, а то је случај са Кишовом књигом Енциклопедија мртвих.

Енциклопедија се код Киша јавља у различитим видовима, од лектире, извора за приповиједање, до идеала коме се писањем тежи. Сјетимо се више пута навођеног интервјуа Данила Киша из 1973. године, поводом Пешчаника:

Мој идеал је био, и остаје до дана данашњег, књига која ће се моћи читати, осим као књига при првом читању, још и као енциклопедија (Бодлерова, и не само његова, најомиљенија лектира), што ће рећи: у наглом, у вртоглавом смењивању појмова, по законима случаја и азбучног (или неког другог) следа, где се један за другим тискају имена славних људи и њихови животи сведени на меру нужности, животи песника, истраживача, поли-

\footnotetext{
${ }^{3}$ Нортроп Фрај тумачи да „у сваком раздобљу књижевности постоје тенденције ка некој одређеној врсти централне енциклопедијске форме” (Фрај 2007: 380).
} 
тичара, револуционара, лекара, астронома, итд., боговски измешани са именима биља и њиховом латинском номенклатуром, с именима пустиња и пешчара, с именима богова античких, с именима предела, с именима градова, са прозом света. Успоставити међу њима аналогију, наћи законе подударности (Киш 1995б: 218).

Успоставити аналогију значило би конструисати ред. Таква књига је и нека врста складишта, што је Кишу драга метафора, па ће то у једном каламбуру претворити у „складиште” (Киш 1995: 180). То, онда, можемо видјети у двоструком значењу: складиште као начин да се чува знање, траг о човјеку, а и да се тражи склад.

Готово тринаест година касније, кад му, у интервјуу поводом Енииклоnедије мртвих, буде поменут тај одломак, опет ће дати виђење једне од кључних карактеристика своје поетике: ,Чињеница је заправо да ова [мисли се на Енциклопедију мртвих - Г. Р.], као и све моје књиге, теже да на неки начин буду енциклопедија, не у смислу знања, него пре - техничког проседеа": за Киша је идеал да се у тексту, „као у музици, смјењују ставови” (Киш 1991: 133). Чак истиче да му је то „опсесивна тема”, појашњавајући да је то „не енциклопедија у смислу сазнања - јер у белетристици основни циљ није сазнајни моменат, мада није ни занемарљив - него енциклопедијски облик у готово метафоричком значењу, коју сву ту прозу света, ту многострукост света може понајбоље да покаже, да прикаже, да одслика" (133).

Тај идеал Киш у својим књигама није остварио у дословном смислу, рецимо, да је написао књигу каква је Павићев Хазарски речник, већ би се прије могло рећи да су Кишове књиге енциклопедијске на извјесне метафоричке начине. Једнако важно, код Киша се тај идеал енциклопедије не јавља само као тежња за енциклопедијском формом, него управо и као тема, као приповиједање о идеалном тексту о коме сањају, некад метафорички а некад дословно, Кишови јунаци. Енциклопедија код Киша је и средство да се говори о сопственом тексту, начину функционисања и сврси, а исто тако и о књижевности уопште. Значи, ту постоји вишеструка метафикционалност.

Метафикцијски аспект је ту иманентан, и не само за Киша, него за енциклопедијски наратив уопште. Како каже Стефано Ерколино, који, видјели смо, тај појам схвата као модус, њега „суштински одређују два својства: 1) енциклопедизам, и 2) метаенциклопедизам, или рефлексија о самом енциклопедизму" (Ерколино 2016: 131). ${ }^{4}$

Овдје бих напоменуо да Киш своје тумачење заснива на формалистичко-структуралистичком виђењу књижевности (гдје се идеје тумаче као мотивација), али је, истовремено свјестан и ограничења таквог приступа, и историјске његове условљености. Но, без обзира на његов експлицитан отпор, сазнајни моменат код Киша је увијек важан.

У вези са тим је и Кишово разумијевање једног старог књижевног поступка, а то је набрајање. Набрајање је, с једне стране, „свођење предмета на слику и прилику света", а, са друге стране, сваки предмет носи своју причу

\footnotetext{
${ }^{4}$ Кларк каже о енциклопедијском дискурсу: „он је антиреалистичан, скреће пажњу на своје принципе селекције и уређивања. У извјесном смислу, енциклопедијски дискурс је метадискурс" (Кларк 1992: 98).
} 
(Киш 1991: 147). За Киша су битни и мотиви ђубришта и гробља (њих ће Киш узети као пјесничке теме), а које можемо схватити као неке врсте метафоре за енциклопедију. За њега, „канта за смеће је, као и гробље, велико складиште света, суштина" (147). Узгред, и сам Кишов спој ђубришта и гробља има нешто раблеовско, карневалско, озбиљно-смијешно, како би рекао Бахтин.

На ниво енциклопедије биће уздигнут и очев Ред вожне, и њему ће управо бити наглашен сазнајни моменат. Тамо ћемо, да поменем само један поступак, имати набрајање од отприлике страницу и по области које у роману Башта, пепео отац користи при писању (Киш 1995a: 45-47). Пешчаник се такође може тумачити као енциклопедијски наратив. Почетак вијенца приповједака Гробнииа за Бориса Давидовича говори да аутор сања о једном идеалном начину да се изложи прича, који је заправо једна енциклопедијска мјешавина гласова и језика̂. Тај модел долази до изражаја и у књизи Енцииклопедија мртвих.

Има код Киша, међутим, и другачијих енциклопедија. Тако јунак насловне приче из књиге Гробница за Бориса Давидовича није добио мјесто у енциклопедији посвећеној Октобарској револуцији (Киш 1995в: 83). Насупрот њему, лик пјесника из посљедње приповијетке, која попут енциклопедијске одреднице носи наслов „Кратка биографија А. А. Дармолатова”, 5 доспио је у стручне књиге из медицине (150), а не из књижевности, што је иронија. Кишова књига га, на неки начин, враћа у књижевну сферу, али као негативан примјер. Из тога слиједи и да енциклопедија има разних - неке теже идеалу (који може бити веома различит), а неке су (намјерно или ненамјерно) непрецизне, лажне чак. ${ }^{6}$ И ти примјери показују да је боље говорити о различитим варијацијама у коришћењу енциклопедијског модела.

Може се проблематизовати канонски карактер енциклопедије. Она заузима позицију post festum, након збивања, попут својеврсне археологије. Проблематичан је и ауторитет који се енциклопедији приписује. Питање је, такође, и да ли енциклопедичност (у дословном, нефикцијском смислу) заиста подразумијева мноштво стилова и жанрова. Такође, да ли енциклопедичност значи и мноштво перспектива? Или је само привид да је тако? Енциклопедије подразумијевају неку врсту обрасца по коме се одреднице најприје бирају, а онда и сачињавају. У славној Енциклопедији просвјетитељи су дали свој (нови) поглед на свијет, и каже се да су тиме припремили Француску буржоаску револуцију. Зар то не говори и да та Енциклопедија није објективна (мада се, што је важно, таквом представља), него има јасну идеолошку усмјереност, вољу да влада и мишљењем о стварности и самом стварношћу, да мијења ту стварност - дакле, показује се да је у њеној основи воља за моћ?

Знање је моћ, морамо се сјетити Фукоа. За енциклопедију важи оно што Фуко каже о архиву: „Архив је пре свега закон онога што може бити речено, систем који уређује појаву исказа као сингуларних догађаја. Архив је исто тако оно што чини да се све те речене ствари не гомилају бескрајно у неко

\footnotetext{
${ }^{5}$ И Проклета авлија има нешто од енциклопедичности. Између осталог, прича о Џем-султану дата је готово као нека енциклопедијска одредница.

${ }^{6}$ Исто важи, наравно, и за историјске књиге, као и за фикцију.
} 
безоблично мноштво, не уписују у непрекидни низ, и не ишчезавају само захваљујући случајном стицају спољашњих околности" (Фуко 1998: 140). Како напомиње Кларк, Фукоов архив је „друго име за енциклопедију - та пракса институционализовања мноштва ствари које треба знати и рећи, и контрола те масе која је потенцијално у нереду као организованог, схватљивог знања" (Кларк 1992: 97).

Сличну идеју наћи ћемо код Борхеса, у приповијеци „Tlon Uqbar Orbis Tertius”, гдје неки научници измишљају један свијет у енциклопедији, па он полако продире у реалност, која доживљава радикалну трансформацију: „Додир и општење с Тлоном довели су до распадања овог света" (Борхес 1963: 39). ${ }^{7}$ И код Киша је важан тај однос текст - стварност, у смислу да фиктивни свијет продире у реални, али са одређеном разликом: то је текст из јунакињиног сна, а онда се открива да подухват сличан томе из сна већ постоји у реалности.

Дејвид Лецлер говори о два приступа енциклопедијској прози, који су у конфликту у вези са питањем о природи таквих текстова: према једном приступу, којем припада и Менделсон, такви текстови поучавају читаоце о свијету, попут, како каже Лецлер, „конвенционалне енциклопедије”;8 други приступ на један постструктуралистички начин сматра да је тај жанр зачет управо „као критика читавог енциклопедијског пројекта” (Лецлер 2012: 306). Треба рећи да се разлике у тим приступима заснивају на различитом виђењу самих енциклопедија (или, можда, на еволуцији енциклопедије). Како формулише Ван Евијк, енциклопедија „може стварати илузију цјелине, али такође, истовремено, разголићује ту илузију” (Ван Евијк 2011: 206).

Сам наслов Кишове приповијетке „Енциклопедија мртвих” упућује на један аспект тематике, а њен поднаслов, „Читав живот”, на други. Сама књига добила је име по тој приповијеци, што би указивало да би књигу требало посматрати као неку врсту енциклопедије мртвих, и аналогну оној о којој говори насловна приповијетка. Такође, указује се и на моралистичку димензију текста. У тим аспектима, односу између појединачне, насловне приповијетке, и цјелине, јасна је сличност са претходном збирком, Гробницом за Бориса Давидовича.

Двосмисленост наслова говори о двострукости тематике: то је, на једној страни, прича о једној (тајној) енциклопедији, идеалном тексту о којем јунакиња, па и аутор књиге, сања, а истовремено је то и прича о недавно преминулом јунакињином оцу коме је посвећена једна одредница те енциклопедије. Другим ријечима, то је метафикцијска прича о писању и читању, а и прича о једном животу.

\footnotetext{
${ }^{7}$ Од више могућих значења, у нашем контексту је илустративно тумачење које даје Бран: „Борхесова прича охрабрује нас да размишљамо о нашем сопственом свијету, посебно како оно што изгледа као именовање или каталогизовање његових елемената - књигама као што су енциклопедије - може заправо утицати на свијет, а не да га само описује" (Бран 2009: 62, истакао аутор).

${ }^{8}$ Јасно је да појам „конвенционалне енциклопедије” никако није саморазумљив и непроблематичан.
} 
Могу се уочити сличности са Проклетом авлијом, која се такође може посматрати барем двоструко: то је прича о фра-Петровом боравку у цариградском затвору и људима које је тамо срео, а истовремено и прича о причању, односно о разним причањима, који се описују, вреднују. Сем тога, ни у једном ни у другом тексту сама причања не допиру до читаоца непосредно, него их увијек износи један „спољни” приповједач, прерађујући и коментаришући. Има и разлика, између осталог и у томе што је код Андрића у игри и однос између усменог приповиједања и писања. ${ }^{9}$

У Кишовој приповијеци користи се стари поступак: на крају текста открива се како је све што је испричано као реалан доживљај заправо сан јунакиње која и приповиједа (у питању је сказ). Наравно, дуж текста дате су индиције о чему је ријеч: већ на почетку, када јунакиња каже како је након очеве смрти кратко боравила у Шведској, па је по повратку још живјела „у том далеком свету као у сну" (Киш 1995г: 43). Јунакињи, која је стручњак за драму и позориште, након представе по Стриндберговој Сонати духова (још један важан детаљ), домаћица, Кристина Јохансон, открива необичну библиотеку, коју ова препознаје као „Енциклопедију мртвих”, па у њој проналази одредницу са биографијом свог оца, и остатак ноћи (дошла је пред поноћ) проводи у читању тог текста. Препричавајући тај текст, она саоштава о очевом животу, али и о самој енциклопедији, о њеном стилу, принципима и циљевима.

Јунакињин сан је реализација жеље, тежње да на губитак оца одговори чувањем сјећања на њега. То је начин да се избори са траумом због очеве смрти.

Име Кристине Јохансон асоцира на Јована Крститеља, који најављује долазак Сина Божијег, и долазак Царства небеског; за њу јунакиња каже да јој је „водич и инструктор” (43), она је упућује у једно тајно знање. У вези је поново са Стриндберговом драмом, гдје је Јохансон име слуге Хумела, главног лика. ${ }^{10}$ Оно што јунакиња ради јесте својеврсна катабаза, силазак у подземље, у земљу мртвих. Сигнал тога је и Соната духова, тј. Сабласна соната, као и брод „Васа”, који је очуван „као каква фараонска мумија”, а и то што је портир назван Кербером (44). Специфичност је што се јунакиња умјесто са оцем сусреће са текстом о њему. Донекле сличан однос као између ознаке и означеног.

Јунакиња открива да у ту, тајну, енциклопедију могу доспјети искључиво они који нису заступљени ни у једној другој. Бављење онима које „званичне” енциклопедије изостављају чини је сличном приповијеци „Гробница за Бориса Давидовича" (а и књизи истог наслова). Сугерише се да је функција књижевности да буде алтернативна историја, да „оживљава успомене”. Уочавамо и разлику. Борис Давидович је изостављен из идеолошких разлога, због

\footnotetext{
${ }^{9}$ Види текст Слободана Владушића „Роман и смрт приповедања”, гдје се у том контексту размотра и Павић, и његов Хазарски речник, такође енциклопедијски облик, у коме је тај облик и афирмисан и оспорен на свој начин (Владушић 2017).

10 Задржавам се на тим детаљима са идејом да покажем колико је Кишов текст густ, тј. колико ствара утисак о томе да сваки елемент има вишеструку фунцкију.
} 
своје изузетности која га је водила да одступи од званичне идеологије, и које ће пак аутора подстаћи на писање. Наспрам тога, састављачи „Енциклопедије мртвих" сматрају да сваки живот вриједи да буде забиљежен. Како формулише јунакиња: „Јер - а то је мислим основна порука Енциклопедије - никад се ништа не понавља у историји људских бића, све што се на први поглед чини да је исто једва да је слично, сваки је човек звезда за себе, све се догађа увек и никад, све се понавља бескрајно и непоновљиво. Стога састављачи Енциклопедије мртвих, тог величанственог споменика различности, инсистирају на појединачном, зато им је свако људско створење светиња" (56).

У том погледу, књига коју Кишова јунакиња сања није права енциклопедија, у смислу да тежи да скупи сва знања, него је то скуп свих биографија „обичних људи”. Такође, јунакиња чита само једну одредницу, о свом оцу, па и она функционише као синегдоха, јер на основу тог текста јунакиња закључује о читавом пројекту. Јунакиња не помиње никакава упућивања на друге одреднице, какве имамо иначе у енциклопедијама и речницима (па и у Павићевом Хазарском речнику, рецимо). Речено савременим термином, та енциклопедија не функционише као хипертекст. Уочљива је двострука улога: јунакиња је читалац, интерпретатор текста, а истовремено и приповједач - једна типична постмодернистичка позиција. ${ }^{11}$

Јунакиња описује ту енциклопедију као идеалну књигу. Она истиче како „није изостављено ту ништа” (54), открива логику састављача: „не постоје у људском животу безначајне ствари и хијерархија догађаја” (61). Те особине и чине, између осталог, ту форму идеалном, али, истовремено, и неостваривом, јер су у питању противрјечне тежње: забиљежити све, сваки детаљ, и описати га подробно и објективно, а истовремено сажимати, сумирати, што подразумијева селекцију, уопштавање, вредновање. Зато се, онда, и не даје директно тај текст, чак се и не цитира бар неки његов дио, него се приповијетка претвара у говорење о читању тог текста, које има двострукост: излаже се садржај, и истовремено коментарише његова форма. Читање те књиге јунакињи даје утјеху, и то у вези са очевом смрћу, али и са општом идејом о томе да иза сваког човјека остаје траг, па, према томе, и иза ње саме. ${ }^{12}$

Стил те енциклопедије јунакиња описује као „невероватни амалгам енциклопедијске лапидарности и библијске речитости" (49). У извјесном смислу, и јунакињин стил такође је амалгам различитих стилова и жанрова.

Визија идеалног текста подривена је вишеструко, на шта упућују различити сигнали. Рецимо, аналогија библиотеке у коју јунакиња одлази са затвором (и била је најприје у затвору), поређење те библиотеке са казаматом (44), портир држи кључеве као чувар Централног затвора (исто), „књиге су биле оковане у негве, као робијаши на галијама, а на ланцима није било локота" (45). Књиге су поређане онамо гдје су код Дантеа људи. Као и код Дантеа налазимо јунака-наратора, који има водича, сусреће се се мртвима и њихо-

${ }^{11}$ Могу се поставити и друга питања, нпр. на ком је језику писана енциклопедија. Мотив сна може се схватити као мотивација, начин да се оправдају евентуалне колизије.

12 То је донекле у вези и са катабазом, која још по античкој митологији наводи јунака да се суочи са сопственом смртности и да превазиђе страх од смрти (види Фелтон 2007: 94). 
вим причама, њиховим животима; због тог поређења са казаматом подсјећа на „Пакао”, сугерише се кажњавање, испаштање, ропство. Оковане књиге, заробљене, као на галијама - указује на то да имају функцију, служе некоме, воде негдје. Све то на нови начин освјетљава оно што се говори у тој Енцииклопедији. Та књига је и облик моћи.

Може се повезати и са ставом аутора из „Post scriptuma” (који тим оквиром текста постаје и имплицитно приређивач насловне приповијетке), гдје говори о писању претпосљедње приповијетке из збирке, под насловом „Књига краљева и будала”: „Намера ми је била да изложим укратко истиниту и фантастичну, 'до невероватности фантастичну', повест Протокола Сионских мудраца, њихов сулуди утицај на генерације читалаца и трагичне последице до којих је то довело; [...]. Да, дакле, једним историјски провереним и мање-више познатим примером доведем под сумњу устаљено мишљење да књиге служе само добру. Свете су књиге, међутим, као и канонизована дела господара̂ мишљења, попут змијског отрова; оне су извор моралности и безакоња, милости и злочина. 'Многе књиге нису опасне. Опасна је само једна"” (107). То је, у извјесном смислу, проблематизовање и саме књижевности, јер и она је један вид утицаја на мишљење, који може прећи у покушај господарења. Важну улогу ту има интерпретација.

Јунакиња наводи да почеци „Енциклопедије” „датирају негде после 1789” (48-49). Та година јасно асоцира на Француску буржоаску револуцију. То се може разумјети као важан сигнал. Не би било неочекивано да се почетак рада на „Енциклопедији мртвих” веже за француско просвјетитељство и славну Енциклопедију (излазила 1751-1772). Код Киша се, дакле, упућује на посљедице те енциклопедије, и на реализацију њених идеја. Другим ријечима, упућује се на ситуацију у којој је књига постала моћ. Можемо то онда тумачити и као истовремену критику, указивање на опасности које постоје у употреби књиге. Осим што може дати добро појединцу, прижити му утјеху, као јунакињи приповијетке, а и, потенцијално, свим људима, припремајући њихово спасење и ослобођење, књига може постати и средство за потчињавање, па и за својеврсно ропство.

„Енциклопедијски текст је”, истиче Кларк, „обиљежен неколиким важним парадоксима: настојећи да тотализује знање и учини га вјечним, писац открива да је пројекат осјенчен непотпуношћу и застарјелошћу; а настојећи да пружи знање на објективан начин, писац мора да се снађе са оним што му је доступно у пројекту обиљеженом идеолошким слијепим мрљама, знањем организованим у категорије одређене културе у одређеном времену” (Кларк 1992: 97).

Тиме би, са поновним обртом, Енцииклопедија мртвих могла да се схвати и као алтернатива просвјетитељској Енциклопедији и Револуцији која је њена посљедица - и то како по идејама (религијски смисао наспрам рационализма), тако и по статусу (тајни пројекат, наспрам оне званичне која је преузела моћ). Постоји, дакле, простор, да се у Кишовом тексту енциклопедија не види само као ослобођење од трауме, нада, него и као сугерисање да је то илузија, а и приказивање човјекове потребе за њом. 
Код Киша се говори о „састављачима” и „редакторима” „Енциклопедије", а не о писцима, нити о ствараоцима. И то се може схватити као сигнал подривања те „Енциклопедије” и њене ауторитативности. Из друге перспективе, проблематизује се и сама идеја писања.

Читаву књигу Енщииклопедија мртвих - и наслов на то упућује - треба схватити као синегдоху једне идеалне енциклопедије. И она је у извјесном смислу слична књизи какву сања јунакиња насловне приповијетке, али је истовремено и подривање те основне идеје о објективности, и свеобухватном знању.

„Релевантност енциклопедијског наратива за модерну жанровску критику може се наћи у чињеници да он покушава да помири људску тежњу да тотализује и контролише са свијешћу да је стварност постала сувише замршена да би се обухватила" (Ван Евијк 2011: 220). Наравно, односи се прије свега на саму књижевност, и поготово на ону Кишову, гдје је та тензија стално присутна, и стално истакнута у први план.

Можда је баш у томе и природа тог идеала. Кад би постојао, он би заправо укинуо приповиједање, јер приповиједање је, заправо, трагање за тим идеалом који се не може никад досећи, и не треба. Оно што преостаје је да се о том идеалу, па и о његовој неостваривости, сања, и да се о тим сновима приповиједа.

\section{ЛИТЕРАТУРА}

Бахтин 1989: M. Bahtin, O romanu, Beograd: Nolit. Preveo Aleksandar Badnjarević.

Бјелински 1948: V. Grigorijevič Bjelinski. Književno-kritički članci. Beograd: Kultura. Prevod: Marko Vidojković.

Борxec 1963: H. L. Borhes, Maštarije. Beograd: Nolit. Preveo Božidar Marković.

Бран 2009: N. Bran, The Cambridge Introduction to Postmodern Fiction. New York: Cambridge University Press.

Ван Евијк 2011: P. van Ewijk. Encyclopedia, Network, Hypertext, Database: The Continuing Relevance of Encyclopedic Narrative and Encyclopedic Novel as Generic Designations. Genre, Vol 44, No. 2, Summer 2011. 205-222.

Владушић 2017: С. Владушић, Роман и смрт приповедања: Жанровска кавга у Проклетој авлији. У: С. Владушић, Књижевност и коментари: упутство за оружану побуну. Београд: Службени гласник. 207-218.

Деретић 1996 (1969): Ј. Деретић. Композищија Горског вијенца, Подгорица: Октоих.

Ерколино 2016 (2014), S. Erkolino. Enciklopedijski modus u modernističkoj i postmodernističkoj prozi, Polja, br. 497 (jan-feb), 128-140. Preveo Predrag Šaponja.

Киш 1991²: D. Kiš, Gorki talog iskustva. Beograd: Bigz. Priredila Mirjana Miočinović. 
Киш 1995a: D. Kiš, Sabrana dela [IV]. Bašta, pepeo.

Киш 1995б: Sabrana dela [IX]. Homo poeticus. Beograd: BIGZ.

Киш 1995в: Sabrana dela [VII]. Grobnica za Borisa Davidoviča.

Киш 1995г:Sabrana dela [X]. Enciklopedija mrtvih.

Киш 1995д: Sabrana dela [XIII]. Skladište. Priredila Mirjana Miočinović.

Кларк 1992: Hillary A. Clark, Encyclopedic Discourse. SubStance, Vol. 21, No. 1, Issue 67. 95-110.

Лецлер 2012: D. Letzler. Encyclopedic novels and the cruft of fiction: Infinite Jest's Endnotes. Studies in the Novel, Vol. 44, Issue 3. 304-324.

Менделсон 1976: E. Mendelson. Encyclopedic Narrative: From Dante to Pynchon. Modern Language Notes, 91, 6 (1976): 1267-75.

Радоњић 2016: G. Radonjić. Fikcija, metafikcija, nefikcija: Modeli pripovijedanja u srpskom $i$ američkom romanu šezdesetih i sedamdesetih godina XX vijeka. Beograd: Službeni glasnik.

Фелтон 2007: D. Felton. The Dead. In: Daniel Ogden (ed.), A Companion to Greek 'Religion. Blackwell Companions to the Ancient World: Literature and Culture. Maiden, Mass., Oxford, UK \& Carlton, Victoria: Blackwell Publishing.

Фрај 2007: Н. Фрај, Анатомија критике: четири есеја. Нови Сад: Orpheus, Београд: Нолит. Превела Горана Раичевић.

Фуко 1998: М. Фуко. Археологија знања. Београд: Плато / Нови Сад: Издавачка књижарница Зорана Стојановића. Превео Младен Козомара.

\author{
Goran M. Radonjić
}

DANILO KIŠ AND THE IDEAL OF THE ENCYCLOPEDIA

(Summary)

The paper discusses the notion of the encyclopedic narrative as a way to describe certain literary texts. Two elements stand out as crucial: knowledge, on the one hand, and genre and stylistic diversity, on the other. Encyclopedia is one of the key motifs in the poetics, both explicit and implicit, of Danilo Kiš, and his texts can also be read as encyclopedic narratives. As regards The Hourglass, Kiš says that his ideal book would be that "which could also be read as an encyclopedia", and in an interview regarding The Encyclopedia of the Dead, he maintains that encyclopedia is his "obsessive topic", and that all his books "tend to be encyclopedias". Here, he points out that this refers more to the literary technique, to the "encyclopedic form in an almost metaphorical sense", than to cognition. In his work encyclopedia features in various forms, such as reading material, source for narration, and, finally, the ideal to which the author aspire through writing. The dream of the heroine in the short story "The Encyclopedia of the Dead" has multiple meanings. It is a fulfilment of a desire, of a need to respond to her father's death by preserving the memory of him. She reveals the Encyclopedia of the Dead, among other things, to be a realization of the ideal of comprehensive knowledge and perfect writing. This ideal, however, is repeatedly undercut, both in the short story itself and in the entire book, while the very book functions as a synecdoche of an encyclopedia. It is also shown that, in addition to being knowledge and consolation, this text can also be understood as a form of power, a way to control our thinking. The tension between human urge to totalize and control things and the awareness that reality has become too intricate to encompass is an important characteristic of Kiš's literature. Kiš shows that books can have various effects, with interpretation playing an important role in the process. 